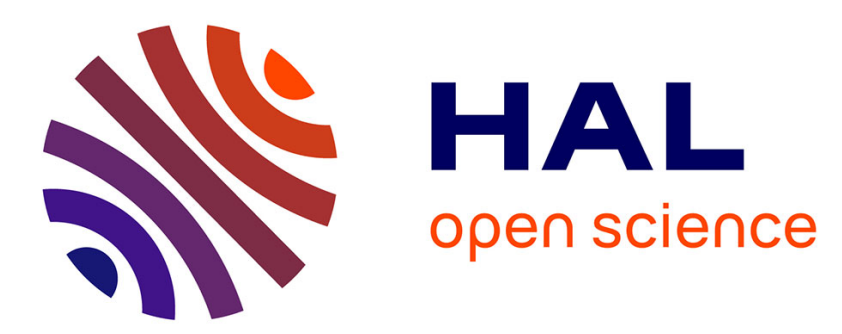

\title{
Electrochemical investigations on crevice corrosion of a martensitic stainless steel in a thin-layer cell
}

\author{
Sabrina Marcelin, Nadine Pébère, Sophie Régnier
}

\section{To cite this version:}

Sabrina Marcelin, Nadine Pébère, Sophie Régnier. Electrochemical investigations on crevice corrosion of a martensitic stainless steel in a thin-layer cell. Journal of Electroanalytical Chemistry, 2015, 737, pp.198-205. 10.1016/j.jelechem.2014.07.008 . hal-01264413

\section{HAL Id: hal-01264413 \\ https://hal.science/hal-01264413}

Submitted on 29 Jan 2016

HAL is a multi-disciplinary open access archive for the deposit and dissemination of scientific research documents, whether they are published or not. The documents may come from teaching and research institutions in France or abroad, or from public or private research centers.
L'archive ouverte pluridisciplinaire HAL, est destinée au dépôt et à la diffusion de documents scientifiques de niveau recherche, publiés ou non, émanant des établissements d'enseignement et de recherche français ou étrangers, des laboratoires publics ou privés. 


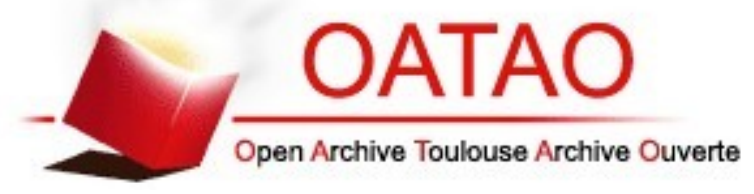

\section{Open Archive TOULOUSE Archive Ouverte (OATAO)}

OATAO is an open access repository that collects the work of Toulouse researchers and makes it freely available over the web where possible.

This is an author-deposited version published in : http://oatao.univ-toulouse.fr/ Eprints ID : 14591

To link to this article : DOI:10.1016/j.jelechem.2014.07.008

URL : http://dx.doi.org/10.1016/j.jelechem.2014.07.008

To cite this version : Marcelin, Sabrina and Pébère, Nadine and Régnier, Sophie Electrochemical investigations on crevice corrosion of a martensitic stainless steel in a thin-layer cell. (2015) Journal of Electroanalytical Chemistry, vol.737. pp.198-205. ISSN 1572-6657

Any correspondance concerning this service should be sent to the repository administrator: staff-oatao@listes-diff.inp-toulouse.fr 


\title{
Electrochemical investigations on crevice corrosion of a martensitic stainless steel in a thin-layer cell
}

\author{
Sabrina Marcelin ${ }^{a}$, Nadine Pébère ${ }^{a, *}$, Sophie Régnier ${ }^{b}$ \\ ${ }^{a}$ Université de Toulouse, CIRIMAT, UPS/INPT/CNRS, ENSIACET, 4 Allée Emile Monso - CS 44362, 31030 Toulouse cedex 4, France \\ b Institut Catholique d'Arts et Métiers, 75, Avenue de Grande-Bretagne, 31300 Toulouse, France
}

Keywords:

Passive film

Depassivation

Impedance

Confined solutions

\begin{abstract}
A B S T R A C T
This paper focuses on crevice corrosion resistance of a martensitic stainless steel. First, electrochemical measurements were performed in deaerated bulk electrolytes for different chloride concentrations and different values of the $\mathrm{pH}$ to determine the critical parameters leading to dissolution or breakdown of the passive film. Then, a thin-layer cell was designed to confine the electrolyte between two parallel stainless steel planes. Impedance measurements obtained for different immersion times and electrolyte thicknesses clearly showed the influence of these two parameters on the crevice corrosion rate. A significant decrease of the corrosion resistance when the medium is increasingly confined was observed. The data obtained in the bulk electrolytes were used to determine the critical conditions in the thin-layer cell which impede the repassivation of the stainless steel $\left(\mathrm{pH}\right.$ and $\left.\left[\mathrm{Cl}^{-}\right]\right)$.
\end{abstract}

\section{Introduction}

Martensitic stainless steels are mainly used for applications where high mechanical performance is required [1,2]. However, due to their low chromium content, they are relatively sensitive to localized corrosion, particularly crevice corrosion encountered in confined environments. In these areas, oxygen is progressively consumed and cannot be renewed by diffusion or convection. Outside the confined area, the cathodic reaction of oxygen reduction still occurs on the metal surface, whereas, in the confined area, the metal surface becomes the anode. The corrosion processes lead to the modification of the chemical composition of the electrolyte in the crevice with simultaneous acidification and an increase of chloride ion concentration [3-5]. When the $\mathrm{pH}$ and the $\mathrm{Cl}^{-}$concentration in the crevice solution reach critical values, depassivation of the stainless steel with active dissolution occurs. This mechanism is the classical one proposed in the literature for the initiation of crevice corrosion. However, the crevice corrosion mechanisms are complex due to the occurrence of different related phenomena such as ohmic drop inside the crevice [6-8] and formation of metastable pits [9-13]. Zadorozne et al. [14] showed that the ohmic drop was not a necessary condition for crevice corrosion propagation for nickel alloys bearing chromium and molybdenum, but was a consequence of the crevice corrosion process. Abdulsalam [8]

\footnotetext{
* Corresponding author. Tel.: +33 534323423.

E-mail address: nadine.pebere@ensiacet.fr (N. Pébère).
}

showed that crevice corrosion on iron in acetate medium $(\mathrm{pH}=4.6)$ started at a potential difference of $0.4 \mathrm{~V}$ between the opening and the bottom of the crevice. In the case of a Ni-Cr-Mo alloy (Alloy-22), which presents a higher corrosion resistance to various forms of localized corrosion, Jakupi et al. [12,13] showed that the kinetics of the cathodic reaction $\left(\mathrm{O}_{2}\right.$ reduction) on passive surfaces outside the crevice are a key factor in crevice corrosion propagation. Under open-circuit potential, the crevice corrosion initiated but the propagation was limited by repassivation. This was attributed to the kinetics of $\mathrm{O}_{2}$ reduction which is too slow to sustain the conditions required for the corrosion propagation within the crevice. To avoid the repassivation of the steel, they applied different currents to the anode. An anodic current density of $250 \mu \mathrm{A} \mathrm{cm}^{-2}$ appeared to be the minimum required to establish active crevice corrosion $\left(5 \mathrm{M} \mathrm{NaCl}, 120^{\circ} \mathrm{C}\right)[12,13]$.

Investigation of crevice corrosion requires reproducing artificial crevices. Different setups have been described in the literature. Based on normalized tests, multiple crevice assembly was often used [14-18]. Cai et al. [17] investigated the effects of applied torque and crevice forming materials on the corrosion behaviour of 316L stainless steel. They showed that the corrosion rate increases with an increase of the applied torque. In other works, the electrolyte was confined on the metal surface by using an insulating plane $[9,19]$. One part of the metal surface, in the confined area, is the anode and another part of the metal surface, in contact with the bulk solution, is the cathode. Na et al. [19] showed, for a ferritic 430 stainless steel, that the initiation time of crevice corrosion 
decreased when the chloride ion concentration increased or when the electrolyte thickness above the stainless steel decreased. Another setup was used where the cathode and the anode were physically separated but electrically connected [9]. Two stainless steel electrodes were used as working electrodes. One was placed in the crevice solution and the other was immersed in the bulk solution. The upper part of the setup was composed of a thin square section PTFE ring. The electrolyte volume in the crevice was limited by the thickness of the PTFE square section ring. A thin-layer cell composed of a Fe-36Ni steel cylinder electrode facing a polymeric cylinder was used by Fiaud et al. [20] to confine the electrolyte. Electrochemical impedance measurements highlighted a radial potential distribution on the steel surface due to the ohmic drop in the cell. Zinc corrosion was also investigated using the same thin-layer cell [21]. The authors showed that when the electrolyte thickness decreased, charge transfer resistance increased. This result was explained by an impoverishment of dissolved oxygen in the confined medium. The major drawback of the different devices mentioned above is the difficulty to accurately control the electrolyte film thickness. Recently, based on the thin-layer cell setup [20,21], an innovative device was developed to minimize the errors of parallelism and to adjust the setting of the electrolyte film thickness $( \pm 20 \mu \mathrm{m})$ [22]. This setup allows a thin electrolyte layer, down to $80 \mu \mathrm{m}$, to be confined between two parallel planes. The electrolyte film geometry can be accurately controlled by using a procedure based on high-frequency impedance measurements on three small platinum electrodes. This setup was used to show the presence of a crevice between copper and aluminium and allowed $\mathrm{pH}$ values inside and outside the crevice to be measured [23].

The aim of the present work was to investigate the corrosion behaviour of a martensitic stainless steel (SS) in confined medium and in crevice corrosion conditions. In a previous work [24], the electrochemical behaviour of the martensitic SS in bulk electrolyte (neutral chloride solution) for different experimental conditions was investigated. To our knowledge, few studies have been reported in the literature concerning the crevice corrosion of a martensitic SS [25]. The chemistry of the electrolyte ( $\mathrm{pH}$ and $\mathrm{Cl}^{-}$ concentration) plays an important role on the depassivation processes. In order to determine these critical values, anodic polarisation curves [26] and impedance measurements were obtained for different $\mathrm{Cl}^{-}$concentrations and/or $\mathrm{pH}$ in deaerated conditions. Then, electrochemical impedance diagrams were obtained for the martensitic SS for various electrolyte thicknesses and for different exposure times in a thin-layer cell.

\section{Experimental}

\subsection{Materials}

The composition in weight percent of the X12CrNiMoV12-3 martensitic stainless steel was $\mathrm{C}=0.12, \mathrm{Cr}=11.5, \mathrm{Ni}=2.5, \mathrm{Mo}=1.6$, $\mathrm{V}=0.3$ and Fe to balance. The microstructure was completely martensitic with residual austenite content less than 1\% [27].

Two types of electrochemical cell were used: a conventional three-electrode cell or a thin-layer cell. The conventional cell was used to determine the critical $\mathrm{pH}$ and $\mathrm{Cl}^{-}$concentration values leading to the depassivation of the martensitic SS. The cell contained a platinum grid auxiliary electrode, a saturated calomel reference electrode (SCE) and a rod of the stainless steel of $1 \mathrm{~cm}^{2}$ cross-sectional area, used as working electrode (rotating disk). The body of the rod was covered with a heat-shrinkable sheath leaving only the tip of the cylinder in contact with the solution. The electrode rotation rate was fixed at $100 \mathrm{rpm}$. A thin-layer cell, designed following previous work by Remita et al. [22], was used to investigate the crevice corrosion of the martensitic SS. Two configurations were used. First, a cylinder of the martensitic SS (10 $\mathrm{mm}$ in diameter) was facing a polymeric cylinder $(30 \mathrm{~mm}$ in diameter) to obtain a restricted volume of electrolyte above the working electrode (Fig. 1a). Then, the polymeric cylinder was replaced by a martensitic SS cylinder (Fig. 1b) which allowed oxygen reduction on the external part of the cylinder to occur. The volume of the solution in the thin-layer cell varied from $565 \mu \mathrm{L}$ to $70 \mu \mathrm{L}( \pm 14 \mu \mathrm{L})$ when the distance between the two cylinders decreased from $800 \mu \mathrm{m}$ to $100 \mu \mathrm{m}( \pm 20 \mu \mathrm{m})$, respectively. The saturated calomel reference electrode and the platinum grid auxiliary electrode were located outside the confined zone.

Prior to any experiment, the stainless steel electrodes were abraded with successive $\mathrm{SiC}$ papers and diamond paste (grade $1000-3 \mu \mathrm{m})$, rinsed and sonicated in ethanol and finally dried in warm air.

As in our previous study [24], the electrolytic solution, used as reference, was prepared from deionised water by adding $0.1 \mathrm{M}$ $\mathrm{NaCl}+0.04 \mathrm{M} \mathrm{Na}_{2} \mathrm{SO}_{4}$ (reagent grade). Then, different solutions were prepared by changing the $\mathrm{Cl}^{-}$concentration, the $\mathrm{pH}$ or both. The $\mathrm{NaCl}$ concentration varied from $0.1 \mathrm{M}$ to $3 \mathrm{M}$. The $\mathrm{pH}$ of the electrolytic solution was decreased by addition of $\mathrm{HCl}$ (Normapur reagent) or $\mathrm{H}_{2} \mathrm{SO}_{4}$ (Carlo Erba reagent) from neutral $\mathrm{pH}$ to 1 . In the conventional three-electrode cell, all the experiments were performed in deaerated conditions. The electrolyte was initially purged with nitrogen for $1 \mathrm{~h}$ then the working electrode was introduced into the cell. $\mathrm{N}_{2}$ bubbling was maintained during the experiment.

\subsection{Electrochemical measurements}

Anodic polarisation curves were obtained under potentiodynamic regulation at a potential sweep rate of $0.6 \mathrm{~V} / \mathrm{h}$ using a Solartron 1287 electrochemical interface. Electrochemical impedance measurements were carried out using a Solartron 1287 electrochemical interface connected with a Solartron 1250 frequency response analyzer. Impedance diagrams were obtained over a frequency range of $65 \mathrm{kHz}$ to a few $\mathrm{mHz}$ with eight points per decade using a $15 \mathrm{mV}$ peak-to-peak sinusoidal voltage. All the measurements were performed at room temperature.

After immersion in the confined media, the working electrode was rinsed with distilled water and ethanol and dried in warm air. The specimens were examined with an optical microscope (Olympus PMG3).

\section{Results and discussion}

First, to determine the critical conditions leading to depassivation of the X12CrNiMoV12-3 stainless steel, anodic polarisation curves and impedance measurements were performed in deaerated conditions for different $\mathrm{NaCl}$ concentrations and different $\mathrm{pH}$ (conventional three-electrode cell). Then, electrochemical measurements were performed in the thin-layer cell in the aerated reference solution. With the first configuration of the thin-layer cell (Fig. 1a), the impedance diagrams were obtained after different immersion times at the corrosion potential $\left(E_{\text {corr }}\right)$ and for different electrolyte film thicknesses in order to characterize the behaviour of the martensitic SS in confined medium. The second configuration (Fig. 1b) was used to reproduce the conditions met during the crevice corrosion. The two martensitic SS electrodes were first electrically connected to induce the initiation and propagation of the crevice corrosion. However, it was not possible to observe the development of the crevice corrosion for long immersion times, as long as 30 days. Thus, the two martensitic SS electrodes were unconnected and the smaller electrode $\left(S=0.78 \mathrm{~cm}^{2}\right)$ was cathodically polarised at $-1 \mathrm{~V} / \mathrm{SCE}$ for $1 \mathrm{~h}$ to remove the oxide film [24]. 


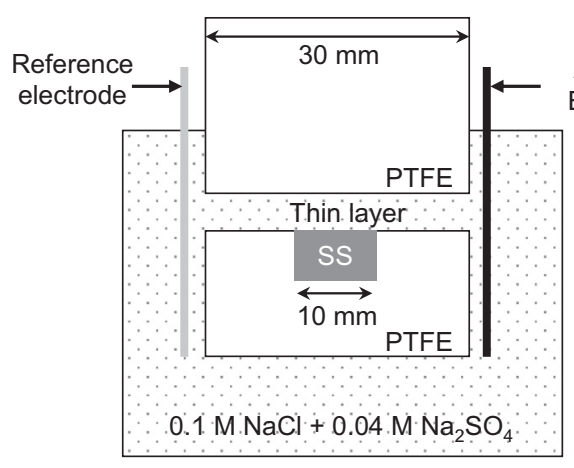

(a) Configuration 1

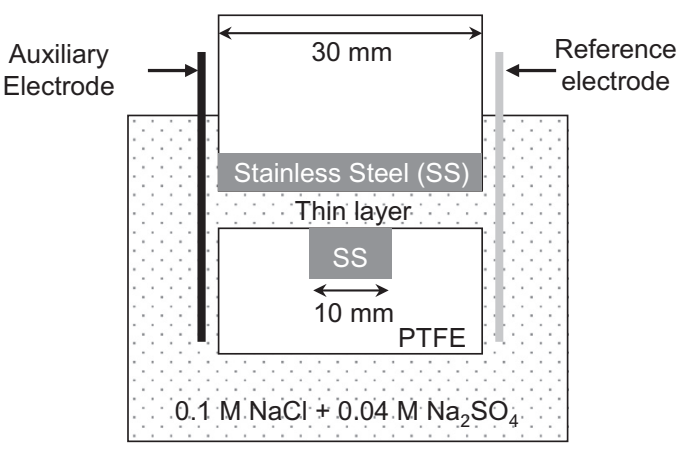

(b) Configuration 2

Fig. 1. Schema of the thin-layer cell used to reproduce: (a) a confined medium (the outer cylinder was inert) and (b) conditions met during crevice corrosion (the outer cylinder was the martensitic SS).

Then, impedance measurements were performed at the corrosion potential on the smaller electrode (working electrode) to investigate the behaviour of the martensitic SS surface as a function of the exposure time.

\subsection{Stainless steel depassivation: determination of critical $\left[\mathrm{Cl}^{-}\right]$and $\mathrm{pH}$}

Fig. 2 gives an example of the anodic polarisation curves obtained for the martensitic SS for three chloride concentrations. For the two lowest $\left[\mathrm{Cl}^{-}\right]$values $(0.2 \mathrm{M}$ and $0.7 \mathrm{M})$, a plateau is observed and the anodic current densities on the plateaux are approximately the same (about $10^{-6} \mathrm{~A} \mathrm{~cm}^{-2}$ ). Then, an abrupt increase of the current density is observed due to the breakdown of the passive film and to the development of pits. For $1 \mathrm{M} \mathrm{NaCl}$, an active peak is observed near $E_{\text {corr }}$ due to the dissolution of the stainless steel. From the anodic polarisation curves, the maximum anodic current density, on the plateau or on the active peak, was reported versus the $\mathrm{Cl}^{-}$concentration (Fig. 3a). Two domains are observed: when $\mathrm{a} \mathrm{Cl}^{-}$concentration threshold is reached, an increase of the current density is observed. Thus, for the lower $\mathrm{Cl}^{-}$concentrations, the SS is protected by the passive film and for $\left[\mathrm{Cl}^{-}\right] \geqslant 0.8 \pm 0.2 \mathrm{M}$, the SS is in the active state and its dissolution occurs. The critical $\mathrm{Cl}^{-}$concentration corresponds to the disappearance of the anodic peak. Similar anodic curves were obtained for different $\mathrm{pH}$ values in the reference solution acidified either with $\mathrm{H}_{2} \mathrm{SO}_{4}$ or with $\mathrm{HCl}$. In this latter case, both the $\mathrm{Cl}^{-}$concentration and the solution $\mathrm{pH}$ were modified. The maximum anodic current density measured on the plateau or on the active peak is reported

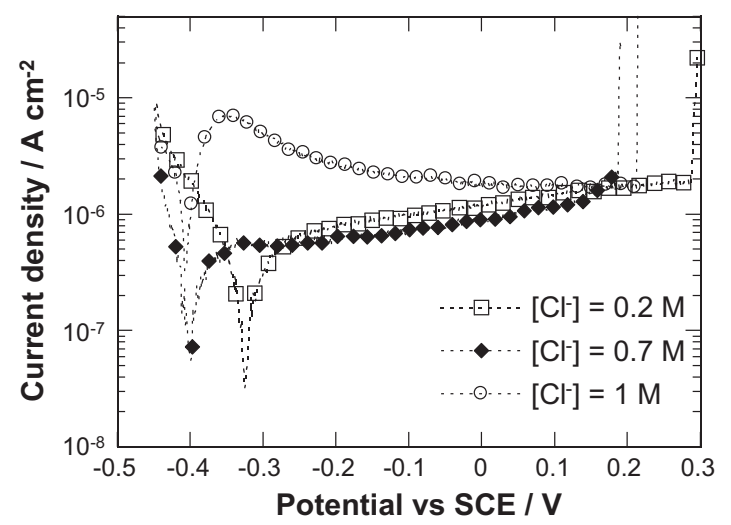

Fig. 2. Anodic polarisation curves obtained for the martensitic SS for different $\mathrm{NaCl}$ concentrations (deaerated conditions). for the different conditions (Fig. $3 \mathrm{~b}$ and c). When the medium is acidified by $\mathrm{H}_{2} \mathrm{SO}_{4}$ (Fig. $3 \mathrm{~b}$ ), the critical $\mathrm{pH}$ value is estimated at $1.5 \pm 0.5$. This value is smaller than that determined with $\mathrm{HCl}$ addition (Fig. 3c) for which the depassivation of the martensitic SS surface occurs for a $\mathrm{pH}=3.2 \pm 0.2$. This result confirms that both the $\mathrm{Cl}^{-}$concentration and the $\mathrm{pH}$ influence the depassivation process $[5,9,14,15]$.

Electrochemical impedance diagrams were also obtained at $E_{\text {corr }}$ for the same deaerated solutions for different $\mathrm{pH}$ and different $\mathrm{NaCl}$ concentrations (not reported here). They were used to measure the electrolyte resistance values, $R_{\mathrm{e}}$, in the high-frequency range and the polarisation resistance values, $R_{\mathrm{p}}$, in the lowfrequency range. Fig. 4 shows the variation of $R_{\mathrm{e}}$ for different $\mathrm{NaCl}$ concentrations and different $\mathrm{pH}$ values of the solution. As expected, $R_{\mathrm{e}}$ decreases when the $\mathrm{NaCl}$ concentration increases or when the $\mathrm{pH}$ is more acidic. These results will be used later to evaluate the electrolyte modifications ( $\mathrm{pH}$ and $\mathrm{Cl}^{-}$concentration) in the thin-layer cell. The variation of $R_{\mathrm{p}}$ versus the $\mathrm{pH}$ of the solution (acidification with $\mathrm{H}_{2} \mathrm{SO}_{4}$ ) is reported in Fig. 5, as an example. Two domains are observed and a $\mathrm{pH}$ value attributed to the transition active/passive can be determined $(\mathrm{pH}=1.6)$ which is in agreement with the $\mathrm{pH}$ range determined from the anodic polarisation curves (Fig. 3b).

We mentioned the difficulty to accurately control the $\mathrm{pH}$ in acidic conditions. However, the procedure allowed some information on the depassivation of the martensitic SS to be obtained.

\subsection{Electrochemical behaviour of the martensitic stainless steel in confined environments}

Fig. 6 illustrates the variation of $E_{\text {corr }}$ for the martensitic SS in the neutral aerated electrolyte for $48 \mathrm{~h}$ (Fig. 1a, configuration 1). For the first $24 \mathrm{~h}$, the polymeric cylinder was located far from the working electrode $(e=1 \mathrm{~cm})$ and it can be considered that the measurement was performed in the bulk electrolyte. It can be seen that $E_{\text {corr }}$ increased progressively with increasing immersion time, in agreement with our previous work [24]. Then, the polymeric cylinder was lowered to obtain a thin electrolyte layer $(e=100 \mu \mathrm{m})$. $E_{\text {corr }}$ progressively shifted in the cathodic direction and it stabilized after $6 \mathrm{~h}$ of immersion ( $30 \mathrm{~h}$ in Fig. 6). This behaviour is attributed to the progressive consumption of dissolved oxygen in the thinlayer cell $[20,21,24]$. The bulk electrolyte remained aerated.

Impedance measurements were performed at $E_{\text {corr }}$ for various thicknesses of the electrolyte film. Fig. 7 shows the impedance diagrams (Bode and Nyquist coordinates) for three immersion times corresponding to the bulk electrolyte $(e=1 \mathrm{~cm}$, Fig. 7a and b) and to a confined medium ( $e=100 \mu \mathrm{m}$, Fig. $7 \mathrm{c}$ and d). For the 

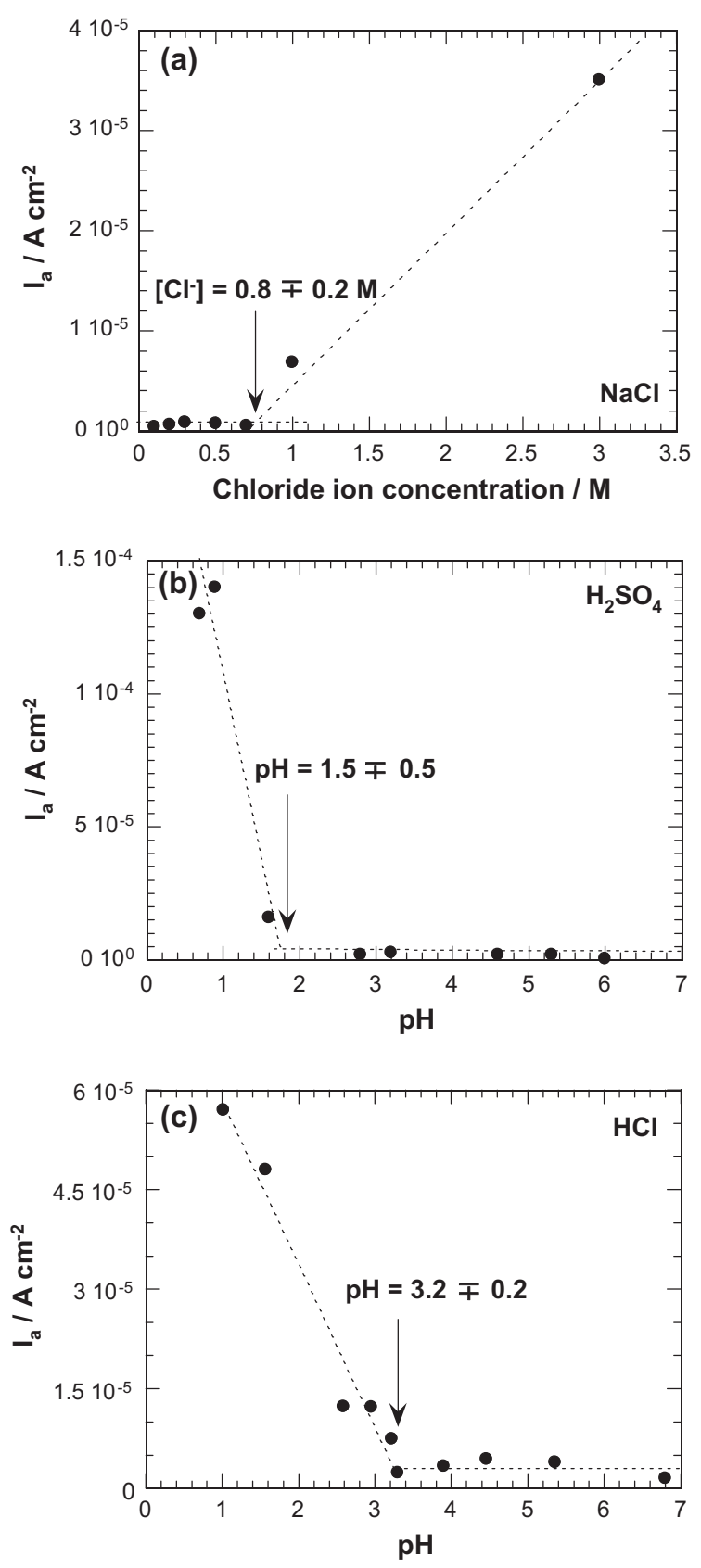

Fig. 3. Maximum anodic current density, $I_{\mathrm{a}}$, obtained from the anodic polarisation curves for: (a) different $\mathrm{NaCl}$ concentrations and different $\mathrm{pH}$ : (b) acidification by $\mathrm{H}_{2} \mathrm{SO}_{4}$ and (c) acidification by $\mathrm{HCl}$.

bulk solution, the impedance diagrams are characterized by a single time constant. In our previous study [24], using a rotating disk electrode, it was observed that the diagrams were characterized by two time constants which were more or less distinct depending on the experimental procedure. The two time constants were attributed to the oxide film (high-frequency domain) and to the charge transfer process (low-frequency range) [24]. In the present study, due to the absence of convection (static conditions), oxygen reduction is limited and the two time constants are not separated. In the bulk electrolyte, it can be seen that the impedance modulus increases with increasing immersion time (Fig. 7a and b) whereas the diagrams are poorly modified in confined medium (Fig. 7c and d). This result is consistent with oxygen depletion when the thickness of the electrolyte layer is reduced. Note that the shape
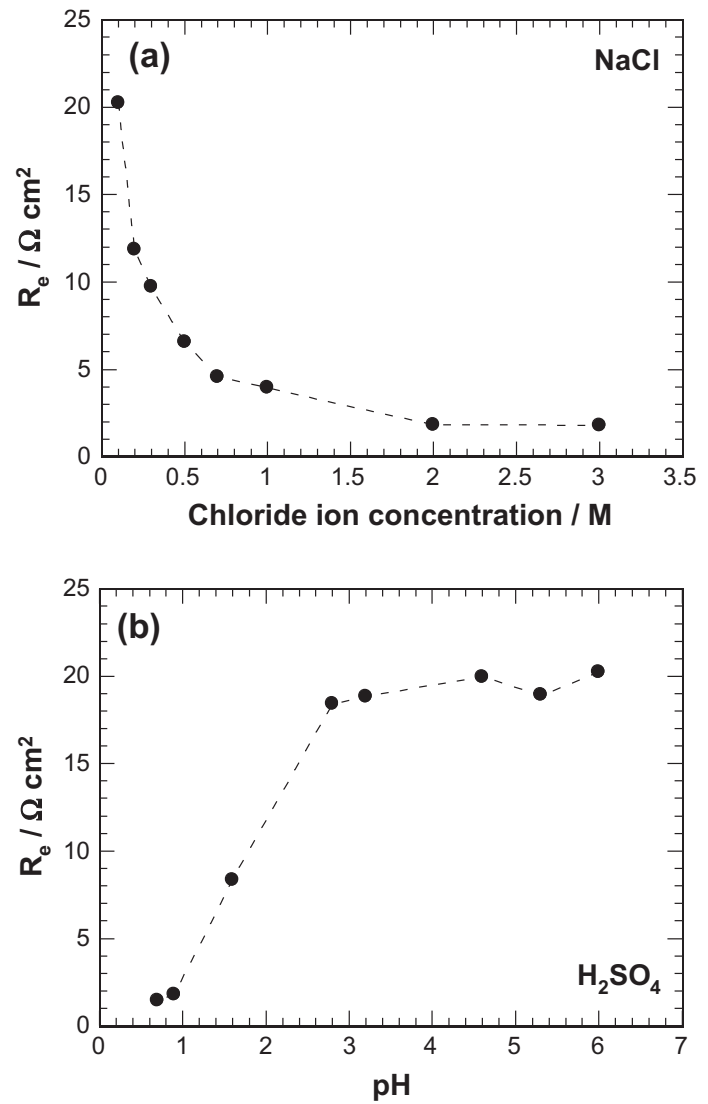

Fig. 4. $R_{\mathrm{e}}$ variation in the deaerated bulk electrolytes as a function of: (a) $\mathrm{NaCl}$ concentration and (b) $\mathrm{pH}$.

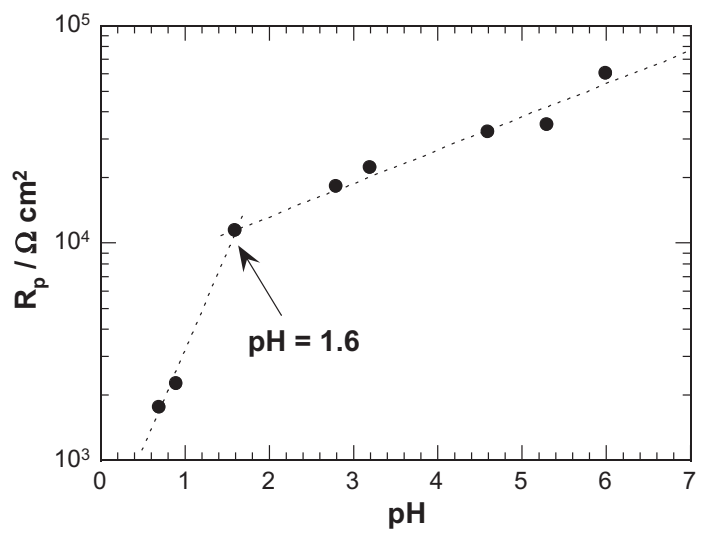

Fig. 5. $R_{\mathrm{p}}$ versus $\mathrm{pH}$ for the martensitic $\mathrm{SS}$ in the deaerated bulk electrolyte (acidification by $\mathrm{H}_{2} \mathrm{SO}_{4}$ ).

of the diagrams in confined electrolyte resembles that obtained in deaerated conditions [24] and thus, the impedance diagrams characterize the passive film.

As in our previous study [24], the parameters associated to the high-frequency part of the diagrams were determined graphically [28]: $R_{\mathrm{ox}}$ represents the oxide film resistance, $\alpha_{\mathrm{ox}}$ and $Q_{\mathrm{ox}}$ are parameters of the constant phase element (CPE). The values of the parameters are reported in Tables 1-3 corresponding to different electrolyte film thicknesses: $1 \mathrm{~cm}, 500 \mu \mathrm{m}$ and $100 \mu \mathrm{m}$, respectively. The electrolyte resistance, $R_{\mathrm{e}}$, was also measured for each thickness. It can be seen that the values of $R_{\mathrm{e}}$ increase when the electrolyte film thickness decreases in agreement with the 


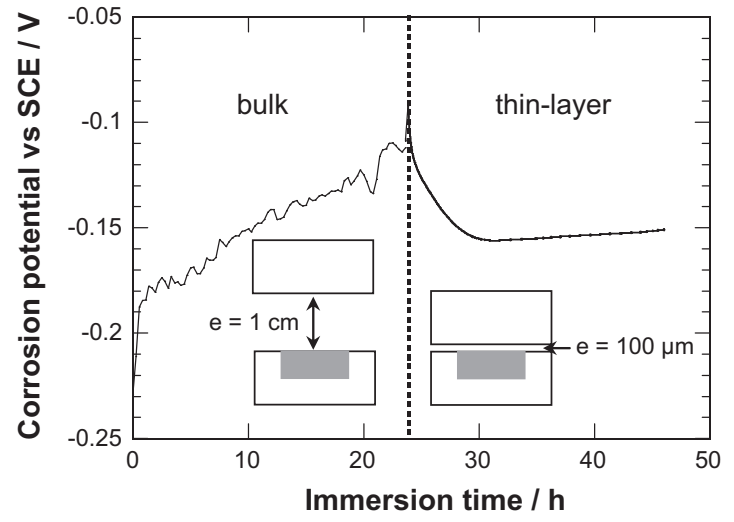

Fig. 6. Variation of $E_{\text {corr }}$ for the martensitic SS during immersion in the aerated solution $\left(0.1 \mathrm{M} \mathrm{NaCl}+0.04 \mathrm{M} \mathrm{Na}_{2} \mathrm{SO}_{4}\right)$; on the left: bulk condition $(e=1 \mathrm{~cm})$ and on the right: confined medium $(e=100 \mu \mathrm{m})$.

principle that the electrolyte resistance, measured on a disk electrode covered by a thin electrolyte layer, depends on the liquid film thickness. For $e=1 \mathrm{~cm}$, the values of $R_{\mathrm{ox}}$ increased and the values of $Q_{\text {ox }}$ slightly decreased when the immersion time increased which can be explained by a modification of the passive layer (composition and thickness) due to the presence of oxygen [24]. In contrast, when the electrolyte layer thickness decreased, the values of $R_{\mathrm{ox}}$ remained relatively unchanged with increasing immersion time in agreement with oxygen depletion.

Then, to investigate crevice corrosion, the upper part of the device was replaced by a martensitic SS sample with a diameter higher than the sample in the lower part (Fig. 1b). The two electrodes were first electrically connected. In these conditions, the confined medium became deaerated and oxygen reduction
Table 1

Parameter values extracted from the impedance diagrams obtained at $E_{\text {corr }}$, for the martensitic SS during immersion in the thin-layer cell (configuration 1). Film electrolyte thickness $=1 \mathrm{~cm}$ (bulk solution).

\begin{tabular}{lllll}
\hline $\begin{array}{l}\text { Immersion time } \\
(\mathrm{h})\end{array}$ & $\begin{array}{l}R_{\mathrm{e}} \\
\left(\Omega \mathrm{cm}^{2}\right)\end{array}$ & $\alpha_{\mathrm{ox}}$ & $\begin{array}{l}Q_{\mathrm{ox}} \\
\left(\mathrm{M} \Omega^{-1} \mathrm{~cm}^{-2} \mathrm{~s}^{\alpha}\right)\end{array}$ & $\begin{array}{l}R_{\mathrm{ox}} \\
\left(\mathrm{k} \Omega \mathrm{cm}^{2}\right)\end{array}$ \\
\hline 2 & 18 & 0.94 & 47 & 85 \\
6 & 18 & 0.94 & 46 & 130 \\
17 & 18 & 0.94 & 42 & 420 \\
\hline
\end{tabular}

Table 2

Parameter values extracted from the impedance diagrams obtained at $E_{\text {corr }}$ for the martensitic SS during immersion in the thin-layer cell (configuration 1). Film electrolyte thickness $=500 \mu \mathrm{m}$.

\begin{tabular}{lllll}
\hline $\begin{array}{l}\text { Immersion time } \\
(\mathrm{h})\end{array}$ & $R_{\mathrm{e}}\left(\Omega \mathrm{cm}^{2}\right)$ & $\alpha_{\mathrm{ox}}$ & $Q_{\mathrm{ox}}\left(\mathrm{M} \Omega^{-1} \mathrm{~cm}^{-2} \mathrm{~s}^{\alpha}\right)$ & $R_{\mathrm{ox}}\left(\mathrm{k} \Omega \mathrm{cm}^{2}\right)$ \\
\hline 2 & 190 & 0.92 & 14 & 800 \\
6 & 190 & 0.92 & 12 & 930 \\
17 & 190 & 0.92 & 10 & 1100 \\
\hline
\end{tabular}

Table 3

Parameter values extracted from the impedance diagrams obtained at $E_{\text {corr }}$ for the martensitic SS during immersion in the thin-layer cell (configuration 1). Film electrolyte thickness $=100 \mu \mathrm{m}$.

\begin{tabular}{lllll}
\hline $\begin{array}{l}\text { Immersion time } \\
(\mathrm{h})\end{array}$ & $\begin{array}{l}R_{\mathrm{e}} \\
\left(\Omega \mathrm{cm}^{2}\right)\end{array}$ & $\alpha_{\mathrm{ox}}$ & $\begin{array}{l}Q_{\mathrm{ox}} \\
\left(\mathrm{M} \Omega^{-1} \mathrm{~cm}^{-2} \mathrm{~s}^{\alpha}\right)\end{array}$ & $\begin{array}{l}R_{\mathrm{ox}} \\
\left(\mathrm{k} \Omega \mathrm{cm}^{2}\right)\end{array}$ \\
\hline 2 & 590 & 0.84 & 22 & 550 \\
6 & 570 & 0.86 & 18 & 740 \\
17 & 600 & 0.85 & 15 & 930 \\
\hline
\end{tabular}
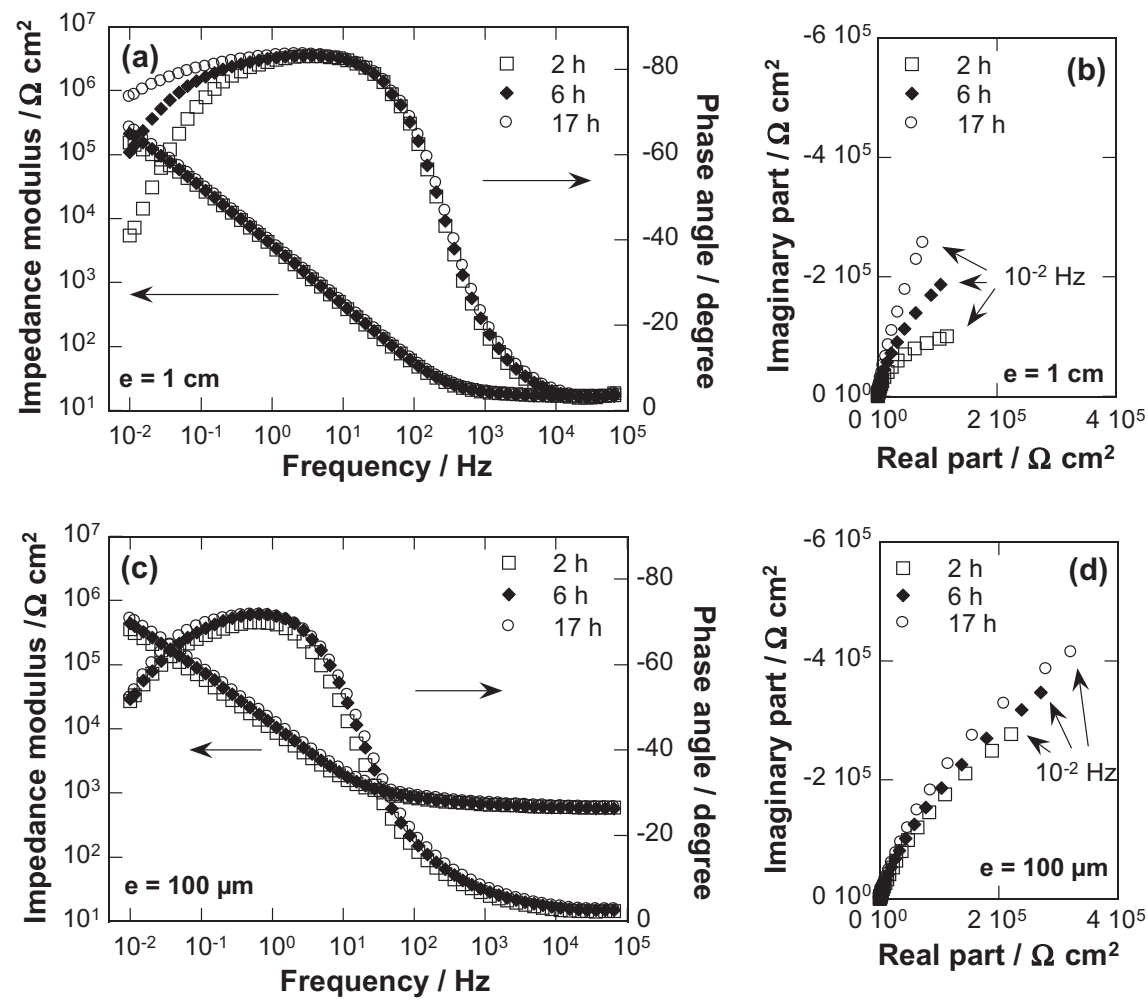

Fig. 7. Electrochemical impedance diagrams in: (a) and (c) Bode representation and (b) and (d) Nyquist representation obtained at $E_{\text {corr }}$ after different hold times in $0.1 \mathrm{M}$ $\mathrm{NaCl}+0.04 \mathrm{M} \mathrm{Na}_{2} \mathrm{SO}_{4}$ solution: (a) and (b) bulk electrolyte and (c) and (d) in confined medium for $100 \mu$ m of electrolyte film thickness (configuration 1 of the thin-layer cell). 
occurred on the external part of the upper SS electrode. As a consequence, the upper SS electrode is the cathode and the lower SS electrode is the anode. Different electrochemical measurements were performed at $E_{\text {corr }}$ for long immersion times, as long as 30 days, with the two electrodes electrically connected, but the development of crevice corrosion was not detected. In the present study, the surface area of the cathode could be too small (external part of the upper SS electrode), compared to the surface area of the anode, to maintain the conditions for the development of the crevice corrosion $[9,12,13]$. A protocol was chosen to overcome this difficulty. The two stainless steel electrodes were unconnected and a cathodic polarisation ( $-1 \mathrm{~V} / \mathrm{SCE}$ for $1 \mathrm{~h}$ ) was imposed on the smaller electrode (working electrode), in the thin-layer cell, to remove the passive film [24]. The dissolution of the passive film induced a modification of the electrolyte composition in the confined medium due to the release of metal ions which was progressively accompanied by both acidification of the solution through hydrolysis and by an accumulation of chloride ions in the thin electrolyte layer [3-5]. Then, the polarisation was stopped and impedance measurements were performed, at the corrosion potential, on the smaller electrode during immersion time to evaluate the ability of the martensitic SS to repassivate in the confined medium. Fig. 8 shows the impedance diagrams plotted after $18 \mathrm{~h}$ of immersion at $E_{\text {corr }}$ in confined media for three electrolyte film thicknesses. Independently of the electrolyte film thickness, the impedance diagrams are characterized by two time constants. The impedance modulus at low frequency sharply decreased from $10^{7} \Omega \mathrm{cm}^{2}$ for $800 \mu \mathrm{m}$ to $3 \cdot 10^{3} \Omega \mathrm{cm}^{2}$ for the most confined medium $(100 \mu \mathrm{m})$ indicating an increase of the corrosion rate of the martensitic SS as the medium becomes increasingly confined.

Fig. 9 shows the impedance modulus, measured at low frequency $\left(|Z|_{L F}\right)$ from the impedance diagrams obtained for different immersion times and for the three electrolyte thicknesses. Two behaviours can be observed. For an $800 \mu \mathrm{m}$-thick layer, $|Z|_{L F}$ decreases during the first hours of immersion and then stabilises after $6 \mathrm{~h}$ at a high impedance value $\left(10^{7} \Omega \mathrm{cm}^{2}\right)$. This result indicates that, at $E_{\text {corr }}$, the passive film was restored. This is attributed to the composition of the confined electrolyte (volume in the thin-layer cell $=565 \mu \mathrm{L})$ which is not sufficiently aggressive $(\mathrm{pH}$ or low chloride concentration) to maintain the depassivation of

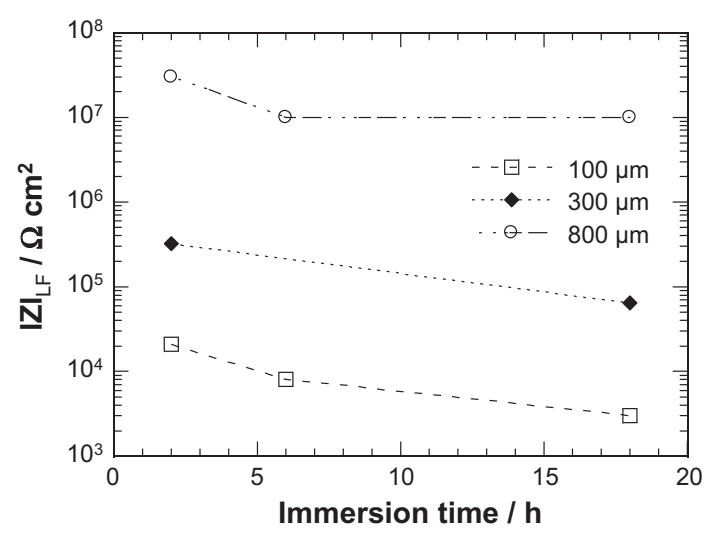

Fig. 9. Impedance modulus at low frequency reported as a function of immersion time for various electrolyte film thicknesses.

Table 4

Values of $R_{\mathrm{e}}, \mathrm{pH}$ and chloride ion concentration reached in the confined medium for different electrolyte thicknesses (configuration 2 of the thin-layer cell).

\begin{tabular}{llll}
\hline Electrolyte thickness $(\mu \mathrm{m})$ & $R_{\mathrm{e}}\left(\Omega \mathrm{cm}^{2}\right)$ & $\mathrm{pH}$ & {$\left[\mathrm{Cl}^{-}\right](\mathrm{M})$} \\
\hline 800 & 8 & 1.5 & 0.4 \\
300 & 5 & 1.3 & 0.6 \\
100 & 3 & 1.1 & 1.2 \\
\hline
\end{tabular}

the martensitic SS surface. Moreover, at $E_{\text {corr }}$, oxygen reduction can also take place on the SS surface because the cathodic reaction is not totally eliminated for this electrolyte film thickness compared to the bulk condition. It was shown that a $1 \mathrm{~mm}$-thick layer corresponds to the bulk electrolyte [22]. For the two other electrolyte thicknesses ( $300 \mu \mathrm{m}$ and $100 \mu \mathrm{m}$ ), the impedance moduli are low and they progressively decrease as the immersion time increases. These observations indicate that the conditions in the confined media are highly aggressive and impede the repassivation of the martensitic SS. The oxide film cannot be rebuilt and corrosion propagates.
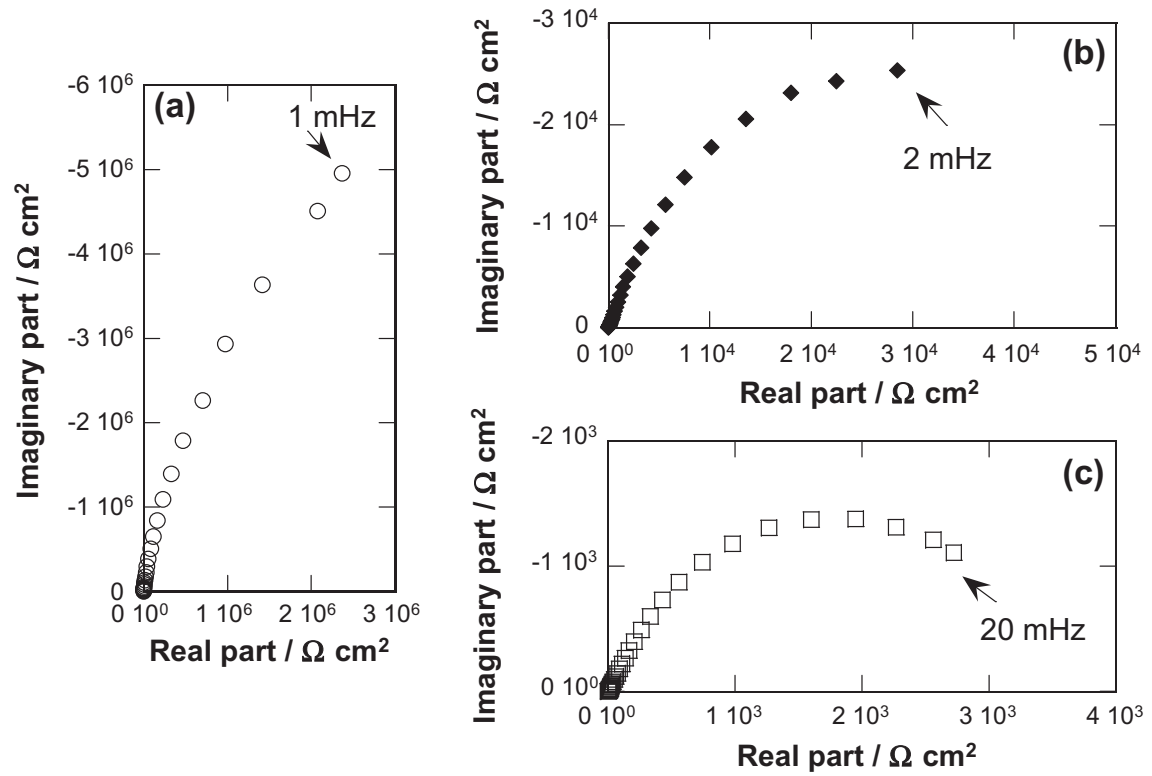

Fig. 8. Electrochemical impedance diagrams (Nyquist representation) obtained at $E_{\text {corr }}$ after $18 \mathrm{~h}$ of immersion in the confined medium for different electrolyte film thicknesses (configuration 2 of the thin-layer cell): (a) $800 \mu \mathrm{m}$, (b) $300 \mu \mathrm{m}$ and (c) $100 \mu \mathrm{m}$. 

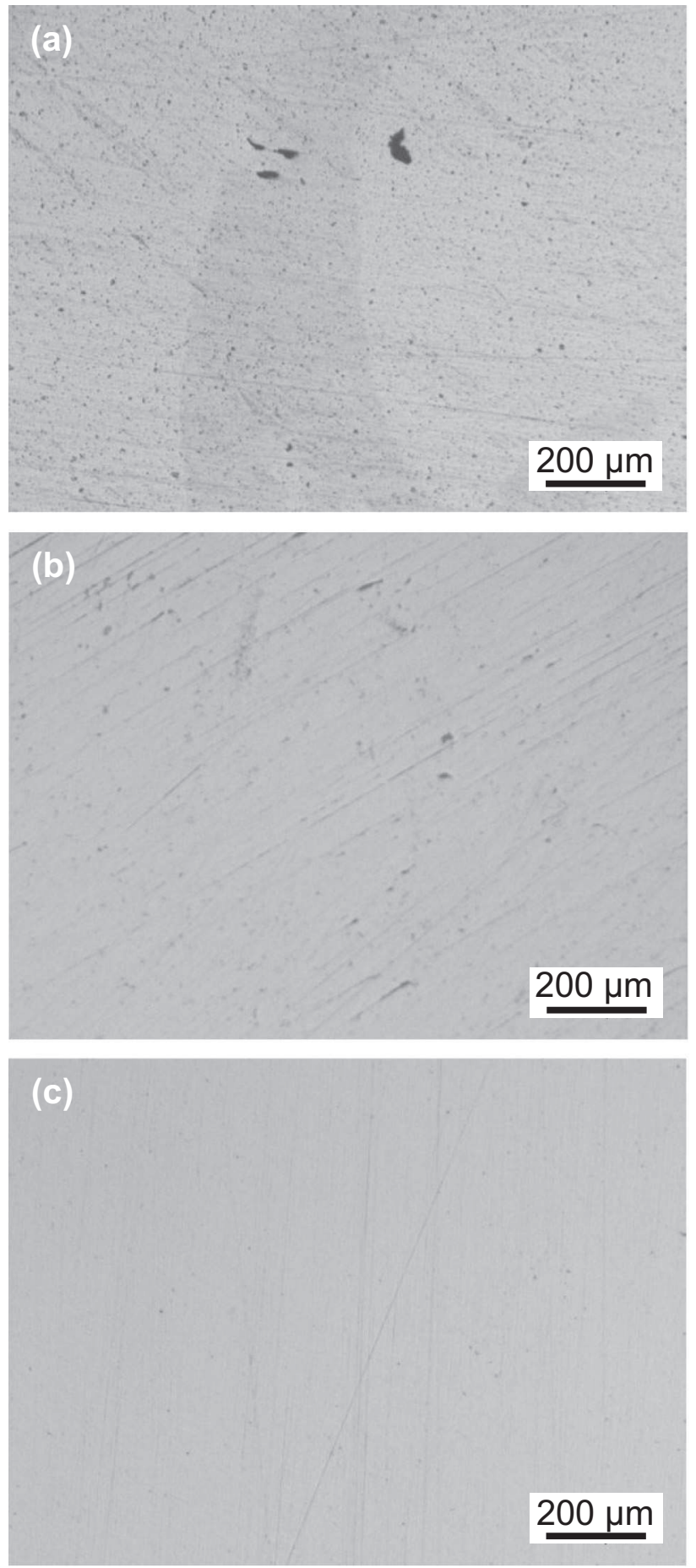

Fig. 10. Optical micrographs of the martensitic SS electrode surface obtained after $18 \mathrm{~h}$ of immersion for various electrolyte film thicknesses: (a) $100 \mu \mathrm{m}$, (b) $300 \mu \mathrm{m}$ and (c) $800 \mu \mathrm{m}$.

The values of $R_{\mathrm{e}}$ obtained in the conventional cell for different values of the $\mathrm{pH}$ and different $\mathrm{NaCl}$ concentrations were compared to the values obtained for different electrolyte film thicknesses (configurations 1 and 2). For configuration 2, the values of $R_{\mathrm{e}}$ are reported in Table 4. The values are low compared to those obtained for configuration 1 (Tables 1-3) and underline significant modifications of the electrolyte $\left(\left[\mathrm{Cl}^{-}\right]\right.$and $\left.\mathrm{pH}\right)$ due to the oxide film dissolution induced by the cathodic polarisation. The values of $R_{\mathrm{e}}$ obtained for configuration 2 are poorly dependent on the liquid film thickness in contrast with the values obtained for configuration 1 ; thus, from Fig. 4, the $\mathrm{pH}$ and the chloride ion concentration of the electrolyte in the thin-layer cell were estimated (Table 4). For the $800 \mu \mathrm{m}$ thick electrolyte film, the composition was $\left[\mathrm{Cl}^{-}\right]=0.4 \mathrm{M}$ or $\mathrm{pH}=1.5$. With these conditions, the passivation of the martensitic SS surface can be maintained and the dissolution of the passive film was limited. In the solution, neither $\left[\mathrm{Cl}^{-}\right]$nor the $\mathrm{pH}$ reach critical values. For more confined environments, $300 \mu \mathrm{m}$-thick and $100 \mu \mathrm{m}$-thick, the electrolyte became more aggressive $\left(\left[\mathrm{Cl}^{-}\right]=0.6 \mathrm{M}\right.$ or $\mathrm{pH}=1.3$ and $\left[\mathrm{Cl}^{-}\right]=1.2 \mathrm{M}$ or $\mathrm{pH}=1.1$, respectively) and the martensitic SS lost its ability to repassivate. For these two electrolyte thicknesses, the estimated critical values which impede passivation of the martensitic SS and lead to severe corrosion are: $\left[\mathrm{Cl}^{-}\right]>0.4 \mathrm{M}$ or $\mathrm{pH}<1.5$.

Optical micrographs of the martensitic SS after $18 \mathrm{~h}$ of immersion in confined medium for the three electrolyte thicknesses are shown in Fig. 10. It can be observed that the density and the size of the corrosion damage increase, in agreement with the impedance results, when the electrolyte thickness decreases.

\section{Conclusions}

The crevice corrosion of a martensitic SS was studied by electrochemical techniques. Thanks to the thin-layer cell, the thickness of the confined electrolyte was accurately controlled $( \pm 20 \mu \mathrm{m})$. The variation of $E_{\text {corr }}$, the disappearance of the low-frequency time constant on the impedance diagrams and the invariance of the diagrams with increasing immersion time, showed a limitation of the charge transfer due to the confined electrolyte which evolved toward a deaerated medium. To investigate crevice corrosion, the martensitic SS electrode was pre-polarised at $-1 \mathrm{~V} / \mathrm{SCE}$ for $1 \mathrm{~h}$. This in situ preliminary treatment induced both an increase of the chloride ion concentration and acidification of the electrolyte in the confined medium. The measurement of the electrolyte resistance indicated that the medium becomes steadily more aggressive with confinement. The impedance modulus at low-frequency revealed that the martensitic SS remained in the passive state for an $800 \mu \mathrm{m}$-thick electrolyte film. But, the crevice corrosion resistance of the stainless steel decreased for lower electrolyte thickness (less than $300 \mu \mathrm{m}$ ). In these confined environments, the critical conditions for the depassivation of the martensitic SS were determined: $\left[\mathrm{Cl}^{-}\right]>0.4 \mathrm{M}$ or $\mathrm{pH}<1.5$. When these conditions are reached, the SS cannot repassivate and the corrosion rate in the crevice increases.

\section{Conflict of interest}

There is no conflict of interest.

\section{Acknowledgments}

This work was carried out in the framework of the ARCAM project, with the financial support of DGCIS, the "Régions Aquitaine, Auvergne and Midi-Pyrénées". The authors gratefully acknowledge the partners of the project: Ratier-Figeac, Aubert \& Duval, Olympus, the Mechanical and Engineering Institute of Bordeaux, the Materials Department of ICAM and the Institute Carnot CIRIMAT.

The authors thank Axel Desnoyers de Marbaix, Eliane Sutter and Bernard Tribollet from the Laboratory LISE (UPMC, Paris) for their help in the development of the thin-layer cell.

\section{References}

[1] D. Thibault, P. Bocher, M. Thomas, J. Mater. Process. Technol. 209 (2009) $2195-$ 2202.

[2] X.P. Ma, L.J. Wang, C.M. Liu, S.V. Subramanian, Mater. Sci. Eng. A 539 (2012) $271-279$. 
[3] J.R. Oldfield, W.H. Sutton, Br. Corros. J. 13 (1978) 13-22.

[4] J.R. Oldfield, W.H. Sutton, Br. Corros. J. 13 (1978) 104-111.

[5] T. Kaji, T. Sekiai, I. Muto, Y. Sugawara, N. Hara, J. Electrochem. Soc. 159 (2012) C289-C297.

[6] A.M. Al-Zahrani, H.W. Pickering, Electrochim. Acta 50 (2005) 3420-3435.

[7] H.W. Pickering, Corros. Sci. 29 (1989) 325-341.

[8] M.I. Abdulsalam, Corros. Sci. 47 (2005) 1336-1351.

[9] Q. Hu, G. Zhang, Y. Qui, X. Guo, Corros. Sci. 53 (2011) 4065-4072.

[10] H.W. Pickering, Mater. Sci. Eng. A 198 (1995) 213-233.

[11] M.I. Suleiman, I. Ragault, R.C. Newman, Corros. Sci. 36 (1994) 479-486.

[12] P. Jakupi, J.J. Noël, D.W. Shoesmith, Corros. Sci. 53 (2011) 3122-3130.

[13] P. Jakupi, F. Wang, J.J. Noël, D.W. Shoesmith, Corros. Sci. 53 (2011) 1670-1679.

[14] N.S. Zadorozne, C.M. Giordano, M.A. Rodríguez, R.M. Carranza, R.B. Reback, Electrochim. Acta 76 (2012) 94-101.

[15] H. Baba, Y. Katada, Corros. Sci. 48 (2006) 2510-2524.

[16] X. He, D.S. Dunn, A.A. Csontos, Electrochim. Acta 52 (2007) 7556-7569.

[17] B. Cai, Y. Liu, X. Tran, H. Li, R. Ji, Corros. Sci. 52 (2010) 3235-3242.

[18] M. Rincón Ortíz, M.A. Rodríguez, R.M. Carranza, R.B. Reback, Corros. Sci. 68 (2013) 72-83
[19] E.Y. Na, J.Y. Ko, S.Y. Baik, Desalination 186 (2005) 65-74.

[20] C. Fiaud, M. Keddam, A. Kadri, H. Takenouti, Electrochim. Acta 32 (1987) 445448.

[21] M. Keddam, A. Hugot-Le-Goff, H. Takenouti, D. Thierry, M.C. Aravelo, Corros. Sci. 33 (1992) 1243-1252.

[22] E. Remita, E. Sutter, B. Tribollet, F. Ropital, X. Longaygue, C. Taravel-Condat, N. Desamais, Electrochim. Acta 52 (2007) 7715-7723.

[23] S. Joma, M. Sancy, E.M.M. Sutter, T.T.M. Tran, B. Tribollet, Surf. Interface Anal., Spec. Issue Article (2013).

[24] S. Marcelin, N. Pébère, S. Régnier, Electrochim. Acta 87 (2013) 32-40.

[25] U.M. Dawoud, S.F. Vanweele, Z. Szklarska-Smialowska, Corros. Sci. 33 (1992) 295-306.

[26] J.L. Crolet, J.M. Defranoux, S. Séraphin, R. Tricot, Les Mém. Sci. Rev. Métall. 71 (1974) 797-805.

[27] M. El May, T. Palin-Luc, N. Saintier, O. Devos, Int. J. Fatigue 47 (2013) 330-339.

[28] M.E. Orazem, N. Pébère, B. Tribollet, J. Electrochem. Soc. 153 (2006) B129B136. 